\title{
WAJAH ISLAM DI BANDAR JALUR SUTERA (Kajian Sejarah Sosial Pada Kesultanan Tidore-Maluku Utara)
}

\author{
Oleh: Muhammad Rais* \\ -Peneliti pada Balai Penelitian dan Pengembangan Agama Makassar \\ Kantor: Jl. A.P. Pettarani No. 72 Makassar \\ Email: Muh Rais@vahoo.com
}

\begin{abstract}
Abstrak
Riset ini menggunakan teknik penjaringan data sejarah secara konvensional dan kajian pustaka sebagai data primer (utama) menganalisis sumber-sumber tertulis, seperti kronik-kronik dan manuskrip-manuskrip klasik, buku-buku sejarah, artikel sejarah, artefak, dan dokumen sejarah sementara sumber data sekunder yang terdiri dari dua cara, yaitu wawancara mendalam (indepth interview) dengan informan utama dan observasi.

Dalam konteks lslamisasi di Kesultanan Tidore, ditemukan beberapa leoriyang mengkonstruk data-data terkait, diantaranya: Teori Arab-meminjam istilah Ahmad Mansur (12 Rabiul Awal 502 Hatau 12 April 1108 M) dibawa oleh empat orangsyekh, Syekh Mansur di Pulau Ternate, Pulau Halmahera dan sekitarnya, Syekh Yakub dengan wilayah syiar Pulau Tidore, Pulau Makian dan sekitarnya, Syekh Amin dan Syekh Umar melakukan syiar Islam di Pulau Halmahera. Kedua, Teori Persia sesuai keterangan Muhammad Jafar Shadiq bahwa Islam telah eksis di Maluku pada abad ke-13: Kedga, Teori Jawa, Jusuf Abdurrahman mengemukakan bukti sejarah, bahwa pada abad ke-14, tepatnya tahun 1465 M, dibawa muballigh bernama Datuk Maulana Husein sudah datang di Ternate dan mengajarkan al-quran, Keempat, Teori Gujarat, teori ini digagas oleh Snaouck Hurgronje. Kelima, Teori Cina, berdasarkan hasil interview dengan Adnan Amal, yang menganggap bahwa Jafar Shadiq yang dimaksudkan banyak kalangan di Maluku Utara sebagai orangArab keturunan Rasulullah SAW. lslamisasi di Kepulauan Tidore dengan tipologi islamisasipola kombinasi antara integratif dan dialog seperti belaku di Sulawesi dan Indonesia Bagian Timur, Kedatangan dan penerimaan Islam berimplikasi pada perbahan-perubahan pada semua lini kehidupan sosial.

Kata Kunci: Sejarah Sosial Islam, Kerajaan Tidore
\end{abstract}

Abstract

This research used a technique of data selection on history in a conventional way and library study as primary (main) data to analyze written sources such as chronicles andclassicalmanuscripts, history books, history articles, artifacts, and history documents, while secondary data sources consisted of two ways, namely in-depth interviews with main primary informants, and observations. In the context of Islamization in Tidore Sultanate, some theories were found to construct related data, among which were: Arab Theory - borrowing the term ofAhmad Mansur (12 Rabiul Awal 502 H or 12 April 1108 AD) was brought by four sheiks, Sheik Mansur on Ternate Island, Halmahera Island and the surrounding. Sheik Yakub with the Islam spread areas on Tidore Island, Makian Island and the surrounding, Sheikh Amin and Sheik Umar spread Islam on Halmahera Island. Second; Persia Theory in line with Muhammad Jafar Shadiq's information that Islam had existed in Maluku in the 13' century; Third, Java Theory, Jusuf Abdurrahman putforward historical evidences that in the $14^{*}$ century, in $1465 A D$ to be exact, it was brought by a clergyman named Datuk Maulana Husein who came to Ternate and taught Al-Quran, Fourth, Gujarat Theory, this theory was the idea of Snaouck Hurgronje. Fifth, China Theory, based on interview results with Adnan Amal, who considered Jafar Shadiq meant by many people in North Maluku as an Arab who was the Prophet Muhammad's (pbuh) descendant. Islamization on Tidore Islands with Islamization typology pattern of combination between integrative and dialogues as practiced in Sulawesi and Eastern Indonesia, the Islam coming and acceptance implicated on changes of every social life line.

Key Words: Social of Islamic History, Kingdom of Tidore.

\section{PENDAHULUAN}

A lur dan proses perjalanan sejarah keindonesiaan yang terkonstruksi dalam khazanah keilmuan yang selama ini memotret Nusantara dengan paradigma tunggal walaupun berangkat dari sejarah lokal yang kaya dengan keragamannya-dengan kecenderungan para sejarawan mendeskripsikan dan menarasikan peristiwa secara ensiklopedis yang popular dengan istilah sejarah lama (old history) dengan fokus utama pada domain politik sebagai variabel utama kajian sejarah Nusantara dengan menegasikan faktor-faktor lain yang melatarbelakangi peristiwa-peristiwa sejarah.
Sejarah seakan linear dan paralel dari awal hingga menjadi Negara Kesatuan Republik Indonesia, sebagaimana yang dimaksudkan teori imperialisme kunonya Soekarno dan teori kolonialisme internal David Brown yang di tengarai salah kaprah bahkan sindrom sejarah oleh Anhar Gonggong.' Sementara tidak terbantahkan bahwa eksistensi Indonesia tidak terlepas dari kontribusi signifikan kerajaan-kerajaan atau pun kesultanan baik kecil ataupun besar terhadapsyiar Islam, integrasi serta kohesi bangsa, dan perjuangan kemerdekaan. 
Namun lamanya pengaruh Islam serta luasnya penyebaran Islam di Nusantara yang direpresentasikan kerajaan/kesultanan lokal tersebut tidak berkorelasi positif dengan sikap kalangan yang berkepentingan untuk mengakomodasinya dalam konstruksi Negara Kesatuan Republik Indonesia sebagaimana layaknya kerajaankerajaan besar yang terlanjur diposisikan sebagai arus utama kerajaan Nusantara. Menurut Komaruddin Hidayat $^{2}$ ada kesan peranan Islam dalam mempersatukan ikatan emosional dan heroisme perjuangan mengusir penjajah serta pembentukan wilayah kepulauan ini "menjadi Indonesia" pun hendak diabaikan.

Terdapat beberapa kesultanan/kerajaan mikro Nusantara-yang terekam dalam manuskrip-manuskrip klasik seperti; Kerajaan Fak-Fak dan Raja Ampat di Papua, Kesultanan Ternate-Tidore, Keultanan Gorontalo, Kerajaan Bugis-Makassar, Kesultanan Buton. Riset ini menemukan posisi strategisnya ditengah ghirah dan keyakinan kalangan ilmuwan bahwa Asia Tenggara, khususnya Indonesia dapat menjadi sebuah masa depan Islam.

Penelitian ini fokus pada beberapa m'asalah penelitian, di antaranya: Bagaimana konstruksi sejarah kesultanan/kerajaan lokal berdasarkan fakta dan peninggalan sejarah yang ada? Bagaimana proses islamisasi pada domain sosial-politik kesultanan/ kerajaan lokal tersebut? Bagaimana dampak perubahan sosial-politik pasca proses islamisasi dalam domain kerajaan/kesultanan lokal?

Menurut Sartono Kartodirjo sebagai kajian sejarah juga terkait eksplorasi struktur masyarakat, pola perilaku dan lain-lain. ${ }^{4}$ Riset ini menggunakan teknik penjaringan data sejarah secara konvensional berupa kajian kepustakaan dengan data primer (menganalisis sumbersumber tertulis, seperti kronik-kronik dan manuskripmanuskrip klasik) dan data sekunder (wawancara mendalam (in-depth interview) dengan informan utama dan observasi). Dipadukan dengan teknik penjaringan data dalam riset sosial dan penelitian sejarah sosial.

\section{TINJAUAN PUSTAKA}

\section{Sejarah Sosial}

Pemanfaatan sejarah sosial dalam penelitian kerajaan-kerajaan lokal dianggap penting sesuai dengan asumsi Kuntowijoyo (1994:35) bahwa sumber sejarah mengenai keluarga bangsawan di masa lalu masih cukup banyak dan tersimpan dengan baik, sehingga dapat merupakan bahan kajian sejarah sosial. Sejarah sosial memerlukan usaha yang membuat kerangka utuh mengenai masyarakat, dengan kata lain yang total atau global, sejarah masyarakat secara keseluruhan.

Dalam penulisan sejarah kerajaan-kerajaan lokal akan mengacu pada model ditekankan oleh Hobsbawn (1972) bahwa setiap penulisan sejarah sosial memerlukan sebuah model, yang sekalipun tidak sangat formal dan terperinci strukturnya, setidak-tidaknya sebagai sebuah kerangka akan tampak lingkaran pusat (central nexus) atau lingkar relasi dari permasalahan yang akan digarap. Dari hasil pembacaan literaturliteratur metodologi sejarah, Kuntowijoyo mengartikulasikan 6 (enam) model, yaitu: 1 ).model evolusi, 2) model lingkaran sentral, 3) model interval, 4) model tingkat perkembangan, 5) model jangka-panjang menengah pendek, dan 6), model sistematis.

Asumsi yang terkonstruksi dari penggunaan model central nexus ala Le Roy Ladurie adalah islamisasi yang merangsek masuk ke ranah kerajaan/kesultanan akan menimbulkan perubahan-perubahan sosial di sekitarnya, karena peranan kerajaan -kesultanan merupakan sentral dari sebuah struktur sosial-politik masyarakat.

\section{Islamisasi di Indonesia}

M.C. Ricklefs sebagaimana dikutip Ahmad Sewang ${ }^{5}$ mendeskripsikan Islamisasi sebagai suatu proses yang tidak pernah berhenti, "Islamisation is a process which has continued down to the present day". Islamisasi yang berlanjut hingga $\mathrm{k} *$ ini dapat diklasifikasi dalam beberapa fase sebagaimana yang diformulasikan oleh J. Noorduyn ${ }^{6}$ yang membagi proses islamisasi untuk domain Sulawesi dalam tiga tahap. 'Pertama; sejak datangnya agama Islam. Kedua; penerimaan agama Islam. Ketiga; penyebaran agama Islam.

Islamisasi dapat dipetakan dalam beberapa domain. Pertama; dengan penerimaan Islam melalui konversi dengan jalan perpindahan agama atau kepercayaan yang dianut sebelumnya kepada agama Islam khususnya ke wilayah pedalaman. Kedua; tesis

Komaruddin Hidayat, et.all, 2006. Menjadi Indonesia: 13 Abad Eksistensi Islam di Bumi Nusantara, Bandung: Mizan, h. xvi

Moeflich Hasbullah, (ed)2000, Asia Tenggara dan Konsentrasi Kebangkitan Islam yang Sedang Bergeser, dalam : Asia Tenggara

Konsentrasi Bam Kebangkitan Islam, Bandung: Fokusmedia, h. 27

+ Sartono Kartodirjo, 1993. Pendekatan Ilmu Sosial dalam Metodologi Sejarah, Jakarta: PT. Gramedia, h. 120

Ahmad M. Sewang, 2005. Islamisasi Kerajaan Gowa: Abad XVI Sampai Abad XVII, Jakarta: Yayasan Obor Indonesia, h. 5

Ibid, h. 4 
yang dikemukakan oleh Mukti Ali dapat di kategorikan Islamisasi melalui jalur politik, yang disebut secara spesifik sebagai tahap pertumbuhan kerajaan-kerajaan Islam (Mukti Ali, 1970:13). Ketiga; tesis Sewang dengan mengajukan pola sosial budaya, yaitu: perubahan yang terjadi secara adaptif atau penyesuaian secara bertahap dari budaya pra-Islam kepada agama Islam.

Dalam penelitian ini fokus pada proses masuknya Islam di ranah Kerajaan/kesultanan Tiore, yaitu: kontak pertama agama Islam dengan masyarakat, penerimaan Islam oleh penduduk dan raja-raja, penyebaran atau syiar Islam secara massif, dan perkembangan kerajaan/ kesultanan lokal yang telah mengalami proses akulturasi dengan Islam.

\section{TEMUAN DAN ANALISIS}

\section{Lanskap Kepulauan Tidore}

Konstruksi sejarah Islamisasi pada Kesultanan Tidore yang memiliki kontribusi politik, ekonomi, dan keagamaan yang mengejawantahkan sisi keunggulan secara komparatif dengan kerajaan atau kesultanan lainnya di Nusantara. Hasil wawancara dengan sekretaris Kesultanan Tidore (AF/65 Thn) ia mengklaim bahwa Pulau Tidore lebih besar dan luas dibandingkan dengan Pulau Ternate. 'Tidore tergolong multietnis dan multikultur (Tidore, Ternate, Makian, maupun Jailolo. Etnis lain; Bugis, Makassar, dan Mandar dan etnis Tionghoa dengan pemukiman (settlement) Cina, perkampungan).

Aggregat penduduk Kepulauan Tiodre 91.930 jiwa yang terdiri dari 45.413 laki-laki dan 46.517 perempuan, dengan laju pertumbuhan per-2008 sebesar 1,29, dengan tingkat heterogetis yang berketegori tinggi, baik pada aspek etnis, kultur, juga tergolong multiagama, dan mengacu pada data monograf Kementerian Agama kota kepulauan Tidore, pemeluk terdiferesiasi kedalam beberapa agama, meliputi penganut agama Islam (Muslim) aggregate 86.794, Protestan aggregate 5637 orang, Katholik aggregat 632 jiwa, Hindu/Buddha sebanyak 20 orang.
Infrastruktur keagamaan, terutama rumah ibadah dalam konteks kota kepulauan Tidore yang menjadi sarana pelaksanaan ibadah dan aktivitas keagamaan lainnya, hampir sama dengan daerah lainnya dengan ketersediaan yang tergolong memadai.Sebagaimana data yang tercatat di Kementerian Agama Kepulauan Tidore per 2008 hanya berjumlahl29 masjid, 110 buah mushalla, dan 29 gereja.

\section{Genealogis dan Stratifikasi Sosial dalam Domain Masyarakat Tidore}

Putuhena mengartikulasi tentorial Maluku dihuni oleh beragam etnis pribumi. ${ }^{8}$ Masinanbow mengelaborasi bahwa persenyawaan dari aspek ras dan kultur ini memicu (triggering) terciptanya kondisi sosio-kultural bahkan sosioliguistikyang memungkinkan berkembangnya segala elemen kebudayaan." Sementara Rush A. Atjo mengemukakan tiga jenjang tratifikasi sosial masyarakat Maluku Utara sebagai berikut: Pertama, Bangsawan, dalam konteks lokal disebut Joou, Kaicil, dan Dano, termasuk segenap keturunan raja. Kedua, Rakyat biasa, yang popular dengan 'Bala' atau "Ana Bala', dan Ketiga, Budak, merupakan strata terakhir. ${ }^{10}$

\section{Lanskap Kesultanan Tidore}

Mengenai genealogis Kesultanan Ternate, memiliki akar sejarah dengan tiga kesultanan lainnya dalam ranah budaya politik Moluku Kie Raha, yang sarat dengan mitos -dalam bentuk tradisi lisan- yang cenderung ditransendensikan dan dipertahankan pihakpihak kedaton Tidore, Ternate, Bacan dan Jailolo, untuk memproteksi keabsahan rasionalisasinya. Mitos" versi pertama dikemukakan Francois Valentijn (1724,11,), yang ditengarai bahwa tradisi lisan ini muncul pada abad ke17 yang mendeskripsikan genealogi keempat kerajaan/ kesultanan. Tradisi lisan kedua yang menarasikan genealogis empat monarki dalam domain Moloku Kie Raha, dikemukakan Van Fraassen (1978, II, 11-12), sebagaimana dirujuk secara lengkap Leirissa $(1999: 59)^{12}$ dengan beberapa penyesuaian bahasa dari peneliti.

Tertimoni salah seorang informan mengatakan bahwa sebelum kedatangan Jafar Shadik, masyarakat

Wawancara di Soasio, Tidore Kepulauan, Jumat, 23 April 2010

Putuhena, Op.cil, h. 337, populsi dengan multiidentintas di Maluku-Utara, menurut Sarasin bersaudara, lanjut Putuhena, berawal dari zaman batu ke zaman tembikar didaerah Maluku sekitar 2000 tahun silam. Bertepatan dengan dimulainya aktivitas ekonomi. Pasca Negroid, datang Orang Malayu dalam dua gelombang, dimulai proto-Melayu kemudian disusul deutro-Melayu. Lihat, Putuhena, 1995. Penyebaran Agama Islam di Maluku, Ujung-Pandang: P3M IAIN Alauddin, h. 21

* R.Z. Leirissa, Op.cit, h. 4-5

Rusli Andi Atjo, Op.cit, h. 28-29

'Lihat. Peter Burke, 2001. History and Social Theory, diterj. Mestiak Zed: Sejarah dan Teori Sosial, Jakarta: Obor Indonesia, h. 152 RZ. Leirissa, Op.cit, h. 59-60. 
sudah memiliki seperangkat pengetahuan dan teknologi sederhana hal tersebut parallel dengan tesis Seno Harbangan Siagian sebagaimana dikutip Alwi Syihab dalam disertasinya (2009) ${ }^{13}$ bahwa setiap orang Indonesia bagaimana pun majunya, tetap terpengaruh oleh agama asli yang sedikit banyaknya melekat pada keyakinan barunya, baik dia seorang pengikut Hindu, Buddha, Islam maupun Kristen. Budaya lokal masyarakat Maluku sebelum kedatangan Islam, menurut Putuhena, berkembangpandangan dunia (Weltanschauung) dengan tipologi monodualistik sebagai basis kultural, bahwa akar budaya masyarakat adalah persatuan. ${ }^{14}$

Implikasi dalam memasyarakatkan persatuan secara konkrit terdapat pada pucak keemasan \{golden age) Kesultanaan Tidore,- setelah mengalami pergulatan sejarah yang panjang sebagaimana dideskripsikan sebelumnya-, dengan jalinan ekonomi, politik maupun budaya dengan monarki-monarki lokal, maupun dengan global. ${ }^{15}$

\section{Islam isasi Pada Ranah Kesultanan Tidore}

Diskursus mengenai masuknya Islam dan proses Islamisasi di wilayah Kesultanan Tidore, dan Maluku Utara secara makro masih sarat dengan polemik yang relatif berkepanjangan sebagaimana paradoksal yang terjadi diberbagai narasi sejarah Nusantara, yang bergerak pada dua bandul pendulum antara mitologi dan fakta sejarah yang diobyektivasi dengan mengacu pada berbagai jaringan yang lebih diwarnai missing links (jejaring yang terputus-putus dan sporadis).

Diskursus di atas, ditengarai Azyumardi Azra dilatari tiga masalah mendasar yakni adanya kecenderungan yang kuat, di mana suatu teori tertentu menekankan terbatas pada beberapa aspek saja dan menafikan aspek-aspek lain dari tiga hal tersebut. ${ }^{16}$ Tesis ini dileborasi Dennys Lombard ${ }^{17}$, masuknya Islam masih sangat kurang dikenal, tak ada alasan apa pun untuk membicarakan-seperti di India misalnyasuatu "penaklukan Islam". Dalam konteks Islamisasi di wilayah Moloku Kie Raha, dan Kepulauan Tidore khususnya, jugatidak luput dari masalah krusial di atas, dengan alotnya kontroversi berbagai versi terkait dengan masuknya Islam, di antaranya;

Pertama, teori Arab-meminjam istilah Ahmad Mansur-, Informan yang notabene sekretaris kesultanan mengemukakan bahwa Islam masuk ke Kepulauan Tidore -terutama dalam domain kesultanan Tidore yang berdiri pada tanggal 12 Rabiul Awal 502 $\mathrm{H}$ atau 12 April $1108 \mathrm{M}$ - dibawa oleh empat orang syekh, pelarian dari Iraq yang mencari suaka politik pada masa revolusi Iraq pada abad ke-VTII, sekaligus syiar Islam, masing-masing bernama Syekh Mansur yang melakukan syiar Islam di Pulau Ternate, Pulau Halmahera dan sekitarnya, Syekh Yakub dengan wilayah syiar Pulau Tidore, Pulau Makian dan sekitarnya, Syekh Ami n dan Syekh Umar melakukan syiar Islam di Pulau Halmahera bagian belakang, meliputi: Patani, Weda, Maba, dan Halmahera bagian utara. ${ }^{18}$ Mengacu pada informasi yang sifatnya oral history (tradisi lisan) ${ }^{19}$. E. K.M. Masinambow dalam bukunya "Halmahera dan Raja Ampat: Konsep dan Strategi Penelitian"mengelaborasi secara lengkap oral history tersebut:

(Menurut tradisi lisan setempat, pada abad kedua Hijriah atau abad kedelapan Masehi, telah tiba di kepulauan Maluku (Utara) empat orang Syekh dari Irak. Kedatangan keempat syekh dikaitkan dengan pergolakan politik di Baghdad-Iraq, di mana golongan Syiah dikejar-kejar oleh pemegang otoritas baik Bani Umayyah maupun Bani Abbasiyah. Keempat orang syekh itu membawa faham Syiah) ${ }^{20}$

Jika informasi tersebut absah, menurut R.Z. Leirizza $^{21}$ maka keempat syaikh tersebut dianggap sebagai orang-orang Islam pertama yang datang di Maluku Utara. Pergolakan politik yang terjadi di Irak

\footnotetext{
" Alwi Syihab, 2009. Al-Tashawwuf Al-Islami wa Atsaruhu fi Al-Tashawwuf Al-Indunisy Al-Mu'ashir , diterj. Muhammad Nursamad: 
adalah peralihan kekuasaan dari Bani Umayyah ke tangan Bani Abbasiyah pada pertengahan abad ke-3 Hijriah. Pada tahun tersebut, yaitu tahun $132 \mathrm{H}$ atau tahun 750 M Daulah Abbasiyah berdiri, lalu memindahkan pusat pemerintahannya dari Kufah ke Baghdad. Daulah Abbasiyah lebih menekankan pembinaan pada pemurnian agama, peradaban dan kebudayaan Islam dari padaekspansi wilayahnyayang memang sudah luas itu.

Kedua, Teori Persia, Putuhena merujuk pada karyaNaidah 'HikayatTernate-sekretaris kesultananmendeskripsikan orang Islam pertama yang mengijakkan kaki di Moluku Kie Raha yang bernama Jafar Nuh atau Muhammad Jafar Shadiq salah seorang keturunan -ahl al-Bait- Nabi Muhammad SAW, "sampe di Ternate bilangan tahon Islam anam ratoes ampat poeloeh tiga anam hdri bulam moeharram harinya isnen ". Penanggalan Naidah dipastikan sesuai dengan kalender yang mencantumkan persamaan antara kalender hijriyah dengan miladiyah atau masehi, yang paralel dengan tanggal 6 Muharram $643 \mathrm{H}$ atau Sabtu 5 Juni 1245 Masehi. ${ }^{22}$ Ini sebagai penanda bahwa Islam telah eksis di Maluku pada abad ke-13. Diakui bahwa ajaran Islam ketika itu belum diaktualisasikan secara paripurna $(<\boldsymbol{\& 5})$, tapi tradisi Islam sudah membumi.

Ketiga, Teori Jawa, Jusuf Abdurrahman ${ }^{23}$ mengemukakan bukti sejarah, bahwa pada abad ke14 , tepatnya tahun $1465 \mathrm{M}$, salah seorang muballigh dari Jawa bernama Datuk Maulana Husein sudah datang di Ternate dan mengajarkan al-quran, terutama pada era kepemimpinan Sultan Zainal Abidin (1486$1500 \mathrm{M}$ ) belajar agama Islam di Giri, Jawa Timur, kemudian menyebarkan ajaran Islam di seantero Maluku. Pada masa itu relasi ekonomi perdagangan dan keagamaan antara Jawa, Ternate dan Tidore sangat intens, lanjut Izra, di wilayah lain pada abad ke-15 seperti Banda, Haruku, Makian, dan Bacan sudah tersebar agama Islam. Relasi ekonomi-dagang inijuga terjalin antara Demak dan Hitu. Joko Suryo ${ }^{24}$ mengelaborasi peranan lembaga pendidikan atau pesantren Giri yang didirikan atas prakarsa Sunan Giri, pesantren ini dikategorikan de Graaf sebagai
"Kerajaan-Ulama" atau Geestelijke Heeren yang didirikan pada tahun $1478 \mathrm{M}$.

Adnan Amal menarik benang merah dari beberapa tesis di atas bahwa agama Islam masuk ke Maluku bukan pada tahun 1486, melainkan sekitar 50 hingga 60 tahun sebelumnya, dan Islam yang masuk ke Maluku Utara berdasarkan keterangan RA.Kern justru melalui jalur pedagang-pedagang Jawa, walaupun tidak menyebut tahun, Kern menduga keras bahwa Islam masuk ke Ternate dan Tidore pada pertengahan abad ke-15. ${ }^{25}$

Keempat, Teori Gujarat, acapkali sejarawan mengklaim bahwa teori ini digagas oleh Snouck Hurgronje, sementara faktanya kontribusi Hurgronje hanya sebatas pengembangan. Azra merujuk pada Drewes mengemukakan bahwa ilmuan yang pertama memformulasikan teori ini adalah Pijnappel yang mengklaim bahwa asal-muasal Islam di Nusantara mengacu ke Anak Benua India bukan Persia atau pun Arabia dan tidak mungkin langsung dari Arabia. Penyiar Islam dite'ngarai bermazhab Syafii, Hurgronje memperkaya teori ini dengan mengemukakan bahwa begitu Islam membumi di beberapa kota pelabuhan di Anak Benua India, Muslim Deccan tersebut sebagian melanjutkan misi sucinya sebagai peletak dasar Islam pertama di Nusantara. Disusul kemudian orang-orang Arab yang secara genealogis mengklaim-diklaim-sebagai keturunan Rasulullah SAW dengan penanda gelar-gelar sayyid dan syarif.Orang-orang Arab ini menurut Hurgronje dalam bukunya Verspreide Geschriften, bertugas di Nusantara sebagai muballig (priest) maupun sebagai muballig-penguasa (priest-prince) atau Sultan. ${ }^{26}$

Teori Gujarat pun tidak lepas dari kritik, salah satunya Syed Naquib Al-Attas, yang secara provokatif menganjurkan agar menolak dan disingkirkan pengenaannya dengan teori yang mengartikulasikan bahwa Islam datang dari India dan dibawa serta disebarkan oleh orang-orang India. Pengukuhan teori ini semakin mengelirukan dan mengarahkan pada kesimpulan-kesimpulan yang sesat. BahkanAl-Attas mengendus motivasi penggagas teori Gujarat sebagai bagian dari teoritis otoktoni atau teori pengarusutamaan (mainstreaming benua dan kebudayaan India dalam peristiwa kebudayaan kepulauan ini. ${ }^{27}$

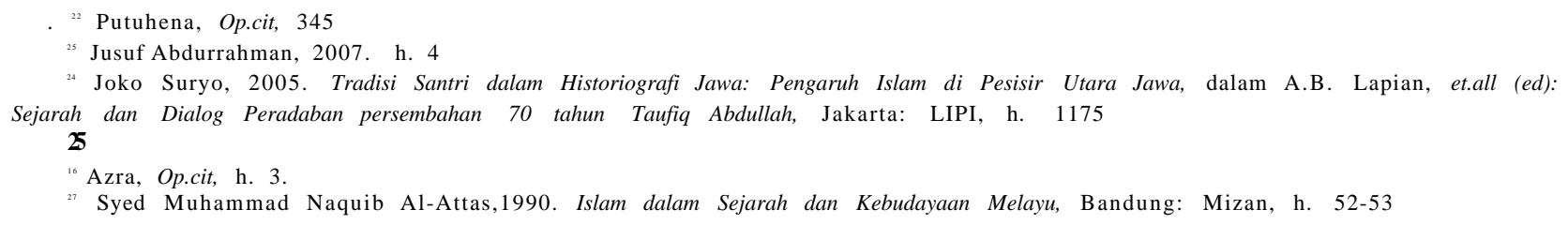


Kelima, Teori Cina, berdasarkan hasil interview dengan Adnan Amal, ${ }^{28}$ yang menganggap bahwa Jafar Shadiq yang dimaksudkan banyak kalangan di Maluku Utara sebagai orang Arab keturunan Rasulullah SAW, sebenarnya orang Cina dengan nama lengkap Sou Tek Ching, dan berprofesi sebagai arsitek perkapalan. Teori Cina juga dapat dicarikan justifikasinya menurut Darsis ${ }^{29}$ pada data-data terkait dengan keberadaan komunitas Tionghoa dahulu yang eksis di Maluku Utara mayoritas Muslim, mata uang yang digunakan melakukan transansi ekonomi juga menggunakan ideom Cina, yaitu Fan, kemudian konsep $\mathrm{Ka} C h i$, sementara data yang terkait dengan ornamen kesultanan, motif pakaian, mahkota dan struktur kesultanan, terutama pada pundak-pundah/kubah kesultanan dan sigi kolano (masjid Raja), sangat kuat pengaruh Cina di dalamnya.

Teori-teori yang mengkonstruksi proses Islamisasi di Nusantara di atas juga memuat saluran yang acapkali digunakan kalangan penyiar Islam, meliputi jalur perdagangan,${ }^{30}$ politik, pendidikan ${ }^{31}$, sosio-kultural dan media keluarga dengan modus amalgamasi melalui pernikahan $^{32}$ dengan perempuan tempatan, bahkan dengan perempuan dikalangan aristokrat sebagai entry point yang memudahkan akses meraka memasuki wilayah istana, mengingat pengaruh istana sebagai sentra kekuasaan, kharisma, popularitas, yang masih sarat dengan budaya paternal istik dan mengandalkan raja sebagai primus inter pares.

\section{Pengaruh Islamisasi dalam Dinamika Sosial- Budaya}

Islamisasi melalui pola dialog-integratif ini tidak terlepas dari peranan raja di kerajaan-kerajaan tersebut yang dielaborasi melalui teori yang gagas oleh Uka Tjanrasasmita bahwa j ika gubernur dan para bangsawan menerima agama baru rakyat akan siap mengikuti, karena dalam adat mereka, dalam tingkat yang berbedabeda, para raja atau sultan mereka dipandang sebagai wakil dari Tuhan di dunia, dikawasan ini menurut Hadi WM penguasa pribumi-maksudnya penguasa lokal-lebih dahulu memeluk Islam, sedangkan penduduk di-islamkan oleh kalangan penguasa. Uka Tjandrasasmita mendeskripsikan peranan raja sebagai primus inter pares dalam tata pemerintahan di kerajaan/kesultanan Tidore beresonansi pada peristiwa monumental terkait denga islamisasi di ranah politik kerajaan. ${ }^{3}$

\section{Islamisasi pada Domain Politik}

Pengaruh transformasi politik nampak jelas pada resktrukturisasi institusi politik yang sebelumnya berbentuk kerajaan dengan gelar kolano yang dilekatkan sebagai pemimpin menjadi kesultanan Tidore, dan gelar kolano disubstitusi menjadi sultan (sebagai pengganti Rasul). ${ }^{34}$ Para pembantunya disebut Bobato Syariat mulai dari jabatan tertinggi Joujau (perdana menteri) hingga gimalaha, memiliki rangkap jabatan sebagai hakim peradilan adat; 2) sumber hukum adalah alquran, sunnah rasul, ijma, dan qias; 3) mengenai majelis hakim; 4) menerapkan prinsip musyawarah; dan 5) mengenai hukum acara. ${ }^{35}$

\section{Islamisasi pada Domain Konstitusi dan Islamisasi pada Ranah Budaya}

Konstitusi kesultanan Tidore yang dikenal dengan Peraturan Kie Se Kolano $1868 \mathrm{M}$ menurut Irham $^{36}$ kedudukannya dapat disejajarkan dengan undangundang dasar atau konsitusi di negara-negara modern pada abad ke-20 ini. Proses formulasinya melalui mekanisme musyawarah ${ }^{37}$-demokrasi Bobato Syariat, pada bagian preambule (pembukaan) Per-aturan Kie Se Kolano (undang-undang dasar) Kesultanan Tidore memuat dua hal pokok, yaitu instruksi sultan kepada dewan menteri dan para bobato lainnya, baik yang berada di pusat pemerintahan maupun yang ada di wilayah.

Perkembangan kebudayaan Islam menurut Putuhena, dapat ditinjau dari dua aspek dalam konteks Islamisasi di Maluku Utara, meliputi: Pertama, daVi segi perluasan wilayah kebudayaan, masyarajak Maluku sejak waktu itu telah termasuk bagian dari pendukung kebudayaan Islam; Kedua, dari segi sustansi kebudayaan. Kebudayaan Islam di Maluku menerima

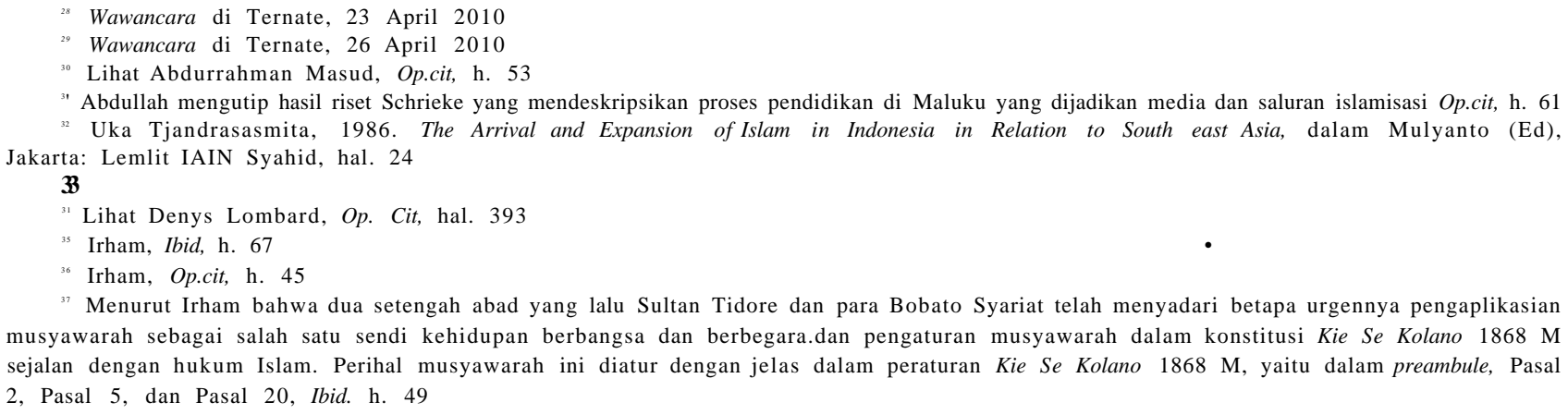
musyawarah sebagai salah satu sendi kehidupan berbangsa dan berbegara.dan pengaturan musyawarah dalam konstitusi Kie Se Kolano 1868 M sejalan dengan hukum Islam. Perihal musyawarah ini diatur dengan jelas dalam peraturan Kie Se Kolano 1868 M, yaitu dalam preambule, Pasal 2, Pasal 5, dan Pasal 20, Ibid. h. 49 
sebagian budaya lokal. Perkembangan melalui akomodasi tersebut, kebudayaan Islam di Moloku Kie Raha bernuansa lokal sebagai pena-ndanya.

\section{Jou Se Ngofa Ngare, Salai Jin, Tradisi Lisan dan Bahasa}

Pandangan dunia Jou se ngofa ngare dapat dideteksi dalam ritual mistik dan srtuktur sosial., yang merupakan tradisi yang eksistensinya sebagai hasil transformasi antara nilai-nilai lokal (local genius) dengan ajaran Islam yang direpresentasikan dalam adagium "Adat matoto agama, agama matoto kitabullah, syariat agama Rasulullah majojoko dorobalolo dale tifa semoro-moro"(Adat bersendikan agama, agama berbasis pada kitabullah, bersyariatkan agama Rasulullah dengan berpijak pada interpretasi kalangan ulama). Pandangan dunia Jou se ngofa ngare mempunyai makna teologis dan sosiologis, deskripsi tentang eksistensi manusia sebagai makhluk yang berasal dari Tuhan, dan dalam konteks pribumisasi, pandangan dunia (world view).

Tarian atau salai Jin hanya dapat dtlaksanakan pada beberapaperistiwa, meliputi: tebusanjanji atau Babeto, pasca kegiatan perbaikan rumah adat (kedaton), atau Goya, upacara pelantikan raja sebagai suatu penghormatan. Ditemukan beberapa tipe sastra yang berasal dari tradisi lisan, di antaranya; Pertama, Dola bololo (peribahasa). Kedua, Dalil Tifa, dan dalil mow (filosofi kehidupan) diiringi tabuh kecil. Ketiga, Bobaso (ungkapan rindu yang didendangkan dalam lirik prosa). Keempat, Moro-moro (sastra lisan yang menampilkan dua group pemain). Kelima, Togal dan Lalayon, (aspek seni, meliputi; tari debus atau dadabus yang sarat dengan wirid dan ratib). Menurut Leirizza bahwa Khusus bahasa yang digunakan penduduk Halmahera Utara dan Maluku pada umumnya tergolong bahasa Austronesia. Pengaruh transformasi Islam pada domain bahasa, sangat dominan pada pemanfaatan bahasa politik Islam misalnya sulthan, khalifat fi al-ardh, baiat, tadbir, abd, majlis, aman, amar, wazir, diwan, syah dan sebagainya bahasa politik Islam $(\leq \mathbf{L} \times \mathbf{X}-<)$ ? I $\left.{ }^{\wedge} \mathbf{L} \mathbf{A}^{\wedge} \mathbf{J I}\right)$ yang banyak bersumber dari bahasa Arab dalam batas tertentu menjadi wahana ekspresi politik Muslim. ${ }^{38}$

\section{PENUTUP}

\section{Kesimpulan}

Diskursus mengenai masuknya Islam dan proses Islamisasi di wilayah Kesultanan Tidore, dan Maluku
Utara secara makro didukung beberapa teori yang mengartikulasikan space and time masuknya agama Islam tersebut masih sarat dengan kelemahan, baik pada aspek validitas maupun reliabilitas data dan fakta sejarahnya.

Dalam konteks Islamisasi di Kesultanan Tidore, ditemukan beberapa teori yang mengkonstruk datadata terkait, diantaranya: Pertama, teori Arab- Islam masuk ke Kepulauan Tidore pada tanggal 12 Rabiul Awal $502 \mathrm{H}$ atau 12 April $1108 \mathrm{M}$ - dibawa oleh empat orang syekh masing-masing bernama Syekh Mansur (Pulau Ternate, Pulau Halmahera), Syekh Yakub (Pulau Tidore, Pulau Makian), Syekh Am in dan Syekh Umar (Halmahera meliputi: Patani, Weda, Maba). Mengacu pada informasi yang sifatnya oral history (tradisi lisan) tersebut diasumsikan bahwa Islam sudah eksis di Tidore, dan jazirah Maluku bagian Utara pada abad ke-8 Masehi atau abad ke-2 Hijriyah, dengan kategori Islam-Syiah. Kedua, Teori Persia, Putuhena merujuk pada karya Naidah 'Hikayat Ternatesekretaris kesultanan-mendeskripsikan orang Islam pertama yang mengijakkan kaki di Moluku Kie Raha yang bernama Jafar Nuh atau Muhammad Jafar Shadiq salah seorang keturunan -ahl al-Bait- Nabi Muhammad SAW, "sampe di Ternate bilangan tahon Islam anam ratoes ampat poeloeh tiga anam hari bulam moeharram harinya isnen ". Penanggalan Naidah dipastikan sesuai dengan kalender yang mencantumkan persamaan antara kalender hijriyah dengan miladiyah atau masehi, yang paralel dengan tanggal 6 Muharram $643 \mathrm{H}$ atau Sabtu 5 Juni 1245 Masehi. Ini sebagai penanda bahwa Islam telah eksis di Maluku pada abad ke-13; Ketiga, Teori Jawa, Jusuf Abdurrahman mengemukakan bukti sejarah, bahwa pada abad ke-14, tepatnya tahun $1465 \mathrm{M}$, salah seorang muballigh dari Jawa bernama Datuk Maulana Husein sudah datang di Ternate dan mengajarkan alquran, terutama pada era kepemimpinan Sultan Zainal Abidin (1486-1500 M) belajar agama Islam di Giri, Jawa Timur, kemudian menyebarkan ajaran Islam di seantero Maluku. Pada masa relasi ekonomi perdagangan dan keagamaan antara Jawa, Ternate dan Tidore sangat intens, lanjut Izra, di wilayah lain pada abad ke-15 seperti Banda, Haruku, Makian, dan Bacan sudah tersebar agama Islam: Keempat, Teori Gujarat, digagas oleh Snaouck Hurgronje, sementara faktanya kontribusi Hurgronje hanya sebatas pengembangan. Paralel dengan Islamisasi di Moluku Kie Raha, dan Kepulauan Tidore khususnya, teori 
Gujarat diatas menemukan justifikasinya sebagaimana data sejarah yang dikemukakan oleh Izra bahwa pada abad ke-13 pedagang-pedagang dari Gujarat dan Asia Barat yang kala itu merupakan sentra-sentra penyebaran Islam, juga turut berdatangan ke Maluku Utara. MC. Ricklefs menemukan korelasinya ketika merujuk pendapat Tome Pires yang mencatat bahwa salah satu rutejaringanperdagangan Maluku, adalah melalui Sumba dan Timur, dan salah satu barang yang diperjual belikan adalah perhiasan-perhiasan dari India. Kelima, Teori Cina, berdasarkan hasil interview dengan Adnan Amal, yang menganggap bahwa Jafar Shadiq (nama Cinanya Sou Tek Ching )adalah orang Arab keturunan Rasulullah SAW. Teori Cina juga dapat dicarikan justifikasinya menurut Darsis pada data-data terkait dengan keberadaan komunitas Tionghoa dahulu yang eksis di Maluku Utara mayoritas Muslim.

\section{Rekomendasi}

1. Perlunya integrasi sejarah Islam di aras lokal dalam kurikulum muatan local atau riil kurikulum pada ranah pendidikan formal dalam upaya pembentukan karakter bangsa yang dikembang menjadi benteng peradaban.

\section{DAFTAR PUSTAKA}

Abdullah DP, 1999. Masuk dan Awal Berkembangnya Islam di Maluku, STAIN Ternate: Hasil Penelitian

Abdurrahman, Jusuf, 2001. Tradisi Lisan Kerajaan Ternate dan Perdagangan Cengkeh dalam Jalur Sutera: Integrasi Laut-Darat dan Ternate sebagai Bandar Jalur Sutera, Prolog dalam Ade Kamaluddin et.all, (ed): Ternate Bandar Jalur Sutera, Ternate: LInTas

Dada Madopo Pangare Ngom Ka Alam Madiki, Manado: Media Pustaka

Amal, Adnan, 2000. Sejarah Islam-Kristen di Galela dan Tobelo, dalam Kasman Hi. Ahmad, et.all (ed): Damai yang Terkoyak: Catalan Kelam dari Bumi Halmahera, Kerjasama Kelompok Studi PODIUM dengan LPAM Pemuda Muhammadiyah Maluku Utara: Madani Press

Al-Attas, Syed Muhammad Naquib, 1984. Islam dalam Sejarah dan Kebudayaan Melayu, Bandung: Mizan

Azra, Azyumardi. 1994. Jaringan Ulama Timur-Tengah dan Kepulauan Nusantara Abad XVII dan XVIII: Melacak Akarakar Pembaruan Pemikiran Islam di Indonesia, Bandung: Mizan

Burke, Peter, 2001. History and Social Theory, diterj. Mestiak Zed: Sejarah dan Teori Sosial, Jakarta: Obor Indonesia

Gonggong, Anhar. 2006. Salah Kaprah terhadap Sejarah Indonesia: Persatuan Majapahit dan Piagam Jakarta-Kemayoritasan Islam, Bandung: Mizan

J.F. Onim, 2006. Islam dan Kristen di Tanah Papua: Meniti Jalan Bersama Hubungan Islam-Kristen dalam Sejarah Penyebaran dan Perjumpaaannya di Wilayah Semenanjung Onim Fakfak. Bandung: Jurnal Info Media

Kartodirjo, Sartono, 1977. Sejarah Nasional Indonesia, jilid II, Jakarta: Depdikbud

Kasijanto, 2001, Sejarah Maluku Utara dalam Susastra Modern Indonesia, dalam Leirizza Jalur Sutera: Integrasi Laut-Darat dan Ternate sebagai Bandar Jalur Sutera, Prolog dalam Ade Kamaluddin et.all, (ed): Temate Bandar Jalur Sutera, Ternate: LInTas

2005. Pedoman Penulisan Sejarah Lokal, Jakarta: Asdep Urusan Sejarah Nasional, Kementerian Kebudayaan dan Pariwisata
2. Perlunya penelitian sejarah lanjutan dengan setting kerajaan-kerajaan lokal lainnya, yang ditengarai masih eksis di Nusantara, dengan pendekatan yang lebih holistik dan komprehensif, dengan orientasi pada revisi sejarah yang selama ini tampak bias dan reduktif, terutama dengan pendekatan filologi untuk mengkaj i kronik-kronik yang memuat sej arah Islam.

3. Konservasi artefak dan peninggalan sejarah kerajaan/kesultanan sebagai cagar budaya dan khazanah budaya Islam yang tak ternilai harganya, terutama melalui ekskavasi arkeologi religi.

\section{Ucapan Terima Kasih}

Penelitian ini dibiayai oleh DIPA Balai Penelitian dan Pengembangan Agama Makassar Tahun Anggaran 2010. Ucapan terima kasih diperuntukkan kepada Kepala Balai Penelitian dan Pengembangan Agama Makassar yang telah mengikutkan saya dalam penelitian ini. Selain itu, ucapan terima kasih kepada Sultan (Jafar Syah) dan Sekertaris Sultan Tidore (Muhammad Amin Faruq) yang telah banyak memberikan informasi. Ucapan terima kasih kepada rekan peneliti pada Balai Penelitian dan Pengembangan Agama Makassar yang senantiasa mendukung, memberikan kritik, saran, dan masukan selama ini.

Kuntowijoyo, 1994. Metodologi Sejarah, Yokyakarta: PT. Tiara Wacana Yokya

Leirissa, R.Z, et.all. 1999. Sejarah Kebudayaan Maluku, Jakarta: Depdikbud RI,

Lombard, Denys, 2008. Le Carrefour Javanais: Essai d'histoire globale II. Les reseaux asiatique, diterj. Winarsih, et.all: Nusa Jawa: Silang Budaya Kajian Sejarah Terpadu Bagian IT. Jaringan Asia, Jakarta: PT. Gramedia Pustaka

Marasabessi, Bunyamin, 2004, Upacara Ritual Salat Jin dan Praktek Para Dukun: Suatu Kontroversi Warisan Budaya, Universitas Khairun, Maluku-Utara: Hasil Penelitian di Tidore dan Ternate

Masud, Abdurrahan, 2006. Dari Haramain ke Nusantara: Jejak Intelektual Arsitek Pesantren, Jakarta: Kencana Prenada Media Grup

Putuhena, M. Saleh, 1995. Penyebaran Agama Islam di Maluku, Ujung-Pandang: P3M IAIN Alauddin,

Rais, Muhammad, 2008. Potensi Organisasi Sosial-Keagamaan: Studi Kelembagaan NU di Maluku, Makassar: Litbang Agama

Rakhmat, Jalaluddin, 1998. Zaman Baru Islam Indonesia: Pemikiran dan Aksi Politik Abdurrahman Wahid, M. Amin Rais, Nurchalish Madjid, dan Jalaluddin Rakhmat, Bandung: Zaman Wacana Mulia

Sewang, M. Ahmad. 2005, lslamisasi Kerajaan Gowa (Abad XVIXVII), Cet.II, Jakarta:Yayasan Obor Indonesia

Rosyidi, Irham, 2009. Sejarah Hukum: Eksplorasi Nilai, Asaz, dan Konsep dalam Dinamika Ketatanegaraan Kesultanan Tidore, Malang: Universitas Negeri Malang Press.

Suryo, Joko, 2005. Tradisi Santri dalam Historiografi Jawa: Pengaruh Islam di Pesisir Utara Jawa, dalam A.B. Lapian, et.all (ed): Sejarah dan Dialog Peradaban persembahan 70 tahun Taufiq Abdullah, Jakarta: LIPI

Syihab, Alwi, 2009. Al-Tashawwuf. Al-Islami wa Atsaruhu fi AlTashawwuf Al-Indunisy Al-Mu'ashir , diterj. Muhammad Nursamad: Antara Tasawuf Sunni dan Tasawuf Falsafi: Akar Tasawuf di Indonesia, Depok: Pustaka Ilman,

Tjandrasasmita, Uka, 1986. The Arrival and Expansion of Islam in Indonesia in Relation to South east Asia, dalam Mulyanto ' (Ed), Jakarta: Lemlit IAIN Syahid 